\author{
CIENCIAMATRIA \\ Revista Interdisciplinaria de Humanidades, Educación, Ciencia y Tecnología \\ Año VII. Vol. VII. N¹3. Julio - Diciembre. 2021 \\ Hecho el depósito de ley: pp201602FA4721 \\ ISSN-L: 2542-3029; ISSN: 2610-802X \\ Universidad Nacional Experimental Francisco de Miranda (UNEFM). Santa Ana de Coro. Venezuela
}

Dra. Lenys Piña-Ferrer

\title{
DOI 10.35381/cm.v7i13.491
}

\section{La Investigación con pertinencia social en post pandemia}

A partir del momento en que la Organización Mundial de la Salud determina que la enfermedad viral provocada por el coronavirus (COVID 19) es una pandemia, surgen situaciones inesperadas, incertidumbres, sorpresas, inseguridad que llevan a la vida de las personas algún tipo de alteración en todo el mundo. Esta situación representa para la sociedad un fenómeno sin precedentes que sacude a las instituciones, donde las educativas se han tenido que enfrentar a decisiones radicales entre ellos el cierre de actividades académicas, administrativas de manera presencial a la modalidad virtual.

En razón de ello, la comunidad educativa, debe tener plena conciencia que al pasar esta situación las consecuencias deben ser asumidas, es decir deben ser convertidas en organizaciones resilientes, producto de ello, se hace necesario que surjan investigaciones con pertinencia social, es decir que vayan dirigidas a poder contribuir con alternativas de solución a las diferentes problemáticas resultantes de la post pandemia, ante ello se requieren individuos críticos, reflexivos, creativos, capaces de tomar decisiones con iniciativa e independencia, es decir que este apto para transformaciones significativas dentro de una sociedad que ha venido siendo trastornada .

De allí entonces las instituciones educativas deben procurar contribuir dentro de sus espacios con formar individuos que coadyuven al logro de una justicia social, con convivencia ciudadana, buscando la legitimidad de la democracia, la participación activa con conciencia humanística que intenten consolidar sociedades más humanas, criticas, reflexivas participativas donde prevalezca el ser como razón fundamental.

Es fundamental realizar investigaciones donde los espacios educativos se vinculen con la realidad producto de la pandemia; de forma comprometida, ética, responsable, con un 


\section{CIENCIAMATRIA}

Revista Interdisciplinaria de Humanidades, Educación, Ciencia y Tecnología

Año VII. Vol. VII. №13. Julio - Diciembre. 2021

Hecho el depósito de ley: pp201602FA4721 ISSN-L: 2542-3029; ISSN: 2610-802X

Universidad Nacional Experimental Francisco de Miranda (UNEFM). Santa Ana de Coro. Venezuela

Dra. Lenys Piña-Ferrer

individuo integro con valores y principios internalizados y preparados para la conformación de equipos de trabajos que puedan hacer uso de las nuevas herramientas digitales y tendencias educativas como factor fundamental para lograr el impacto en el entorno.

Para llevar a cabo esta formación integral "permanente y postpandémica", debemos optimizar nuestras relaciones con el medio ambiente y mejorar continuamente las habilidades que poseemos como seres humanos de manera que ante cualquier eventualidad indebida podamos tener la capacidad de reorientarla y con ello estar preparados en la producción eficiente de haberes y saberes, para lograr el desarrollo del país y por ende de la humanidad.

Dra. Lenys Piña-Ferrer

lenyspina@iieakoinonia.org

Instituto de Investigación y Estudios Avanzados Koinonía, Santa Ana de Coro Venezuela

https://orcid.org/0000-0002-9493-7499 